\title{
Role of laparoscopic techniques in the treatment of female genital pathology
}

\author{
Amer Šuškić ${ }^{1 *}$, Sanela Halilović Šuškić ${ }^{2}$ Dejan Oprić ${ }^{3}$, Siniša Maksimovićc ${ }^{4}$
}

\author{
${ }^{1}$ Department of Obstetrics and Gynaecology, General hospital Travnik, Travnik, Bosnia and Herzegovina \\ ${ }^{2}$ Department of Internal Medicine, General hospital Travnik, Travnik, Bosnia and Herzegovina \\ ${ }^{3}$ Department of Pathology, Medical Faculty University of Belgrade, Belgrade, Serbija \\ ${ }^{4}$ Department of Oncological surgery, Public Hospital, St.Vracevi, Bijeljina, Bosnia and Herzegovina
}

Received: 09 September 2016

Accepted: 05 October 2016

\author{
*Correspondence: \\ Dr. Amer Šuškić, \\ E-mail: suskic@bih.net.ba
}

Copyright: () the author(s), publisher and licensee Medip Academy. This is an open-access article distributed under the terms of the Creative Commons Attribution Non-Commercial License, which permits unrestricted non-commercial use, distribution, and reproduction in any medium, provided the original work is properly cited.

\begin{abstract}
Background: Laparoscopy or endoscopically examining the peritoneal cavity was first attempted in 1901 by George Kelling who called this examining procedure celioscopy. Laparoscopy provides direct visual access to inner pelvic anatomy without a major abdominal surgery so that anatomy of uterus, ovaries, and fallopian tubes can be studied in more details and abnormalities can be treated at the same time.

Methods: This was a retrospective study which presents the results of laparoscopic treatment of various gynecological diseases in Cantonal hospital Travnik, Bosnia and Herzegovina in the period from 2003 to 2016 . Total 295 cases were enrolled. All underwent laparoscopic surgery in general anesthesia. The results were statistically analyzed.

Results: The total number of patients is 295. The incidence is highest in the age 20-49 with a peak of 30-39 years $(41.35 \%)$. Ovarian cysts are most common pathological condition in $43.60 \%$, Infertility in $16.39 \%$ and Ectopic pregnancy in $12.13 \%$. The most commonly treatment was cystectomy $40.06 \%$, then chromopertubation with ovarian drilling 18:29\% in infertility, and adnexectomy $10.72 \%$.

Conclusions: Laparoscopy involves a minimal damage to body tissues. It is safer than open surgery. Laparoscopic treatment has contributed to faster treatment, faster recovery and reducing the cost of treatment, and thus raise the level of efficiency.
\end{abstract}

Keywords: Celioscopy, General anesthesia, Laparoscopy

\section{INTRODUCTION}

Laparoscopy or endoscopically examining the peritoneal cavity was first attempted in 1901 by George Kelling who called this examining procedure "Celioscopy". In the early 1930's, the first reports of laparoscopic interventions for nondiagnostic purposes were published. Initial procedures included lysis of abdominal adhesions and diagnostic biopsies of abdominal organs under direct visualization. Throughout the 1960's and 1970's, laparoscopy became a vital part of gynaecological practice. Despite these technological advances, it was not until after 1986, following the development of a video computer chip that allowed the magnification and projection of images onto television screens, that the techniques of laparoscopic surgery truly became integrated into the discipline of general surgery. The first laparoscopic cholecystectomy performed on a human patient was done in 1987 by the French physician Mouret. The rapid acceptance of the technique of laparoscopic surgery by the general population is unparalleled in surgical history. It has changed the field of general surgery more drastically and more rapidly than any other surgical milestone. ${ }^{1}$ Laparoscopy provides 
direct visual access to inner pelvic anatomy without a major abdominal surgery so that anatomy of uterus, ovaries, and fallopian tubes can be studied in more details and abnormalities can be treated at the same time. ${ }^{2}$

\section{METHODS}

In this retrospective study, we present the results of laparoscopic treatment of gynaecological diseases in Cantonal hospital Travnik, Bosnia and Herzegovina in the period from year 2003 to 2016. During this period, we treated 295 patients with different gynaecological diseases and conditions. All patients were hospitalized for the planned treatment; diagnosis is established after gynaecological and sonographic exam. Patients with morbid obesity, severe hypertension, coronary artery disease, acute bronchitis, chronic obstructive lung disease and patients with urinary tract infection were excluded from the study. After applying general anesthesia, the vulva, vagina, and perineum were cleaned with iodine solution in the lithotomy position, and a bladder catheter was applied. The site was covered with sterile cloths, a 3$4 \mathrm{~mm}$ vertical incision was made below the umbilicus, and a Verres needle was inserted into the abdomen. To determine whether the needle was in the abdomen via the serum physiological test, $\mathrm{CO}_{2}$ gas was blown into the abdomen to achieve abdominal distension. After adequate distension was achieved, the vertical incision was enlarged to $1-2 \mathrm{~cm}$, a $10 \mathrm{~mm}$ trocar was placed in the abdomen, and the patient was brought into a $20^{\circ}-25^{\circ}$ Trendelenburg position. For better manipulation and visualization of the pelvic organs, a second and third trocar of $5 \mathrm{~mm}$ and $10 \mathrm{~mm}$ was inserted into the abdomen, and the pelvic mapping process and laparoscopic surgery was initiated.

\section{RESULTS}

Table 1: Demographic characteristics of women undergoing laparoscopic surgery.

\begin{tabular}{|lll|}
\hline Age in years & No. of Patients & Percentage \\
\hline 10-19 year & 17 & 5.76 \\
\hline 20-29 year & 85 & 28.82 \\
\hline 30-39 year & 122 & 41.35 \\
\hline 40-49 year & 45 & 15.25 \\
\hline 50-59 year & 15 & 5.09 \\
\hline 60-69 year & 8 & 2.71 \\
\hline 70-79 year & 3 & 1.02 \\
\hline Total & 295 & 100.0 \\
\hline
\end{tabular}

The total number of patients treated by various gynaecological diseases is 295. Table 1 shows the demographic characteristics of patients undergoing laparoscopic surgery. The incidence is highest in the age $20-49$ with a peak of $30-39$ years $(41.35 \%)$
Table 2: Laparoscopic findings of women undergoing laparoscopic surgery.

\begin{tabular}{|lll|}
\hline $\begin{array}{l}\text { Characteristic } \\
\text { findings }\end{array}$ & No. of patients & Percentage \\
\hline Ovarian cyst & 133 & 43.60 \\
\hline Infertility & 50 & 16.39 \\
\hline Ectopic pregnancy & 37 & 12.13 \\
\hline Endometrioma & 32 & 10.49 \\
\hline $\begin{array}{l}\text { Ovarian cystic } \\
\text { tumor }\end{array}$ & 20 & 6.55 \\
\hline Carcinosis peritonei & 2 & 0.65 \\
\hline Polycystic ovary & 2 & 0.65 \\
\hline Sterilization & 6 & 1.97 \\
\hline Haematosalpinx & 4 & 1.31 \\
\hline Hydrosalpinx & 4 & 1.31 \\
\hline Sy PCO & 2 & 0.65 \\
\hline Pelveoperitonitis & 2 & 0.65 \\
\hline Ascites & 2 & 0.65 \\
\hline Molla hydatidosa & 1 & 0.32 \\
\hline Descensus uteri & 1 & 0.32 \\
\hline Teratoma ovary & 2 & 0.65 \\
\hline Uterine prolapse & 2 & 0.65 \\
\hline Total & 305 & 100.0 \\
\hline
\end{tabular}

Table 3: Methods of laparoscopic surgical procedures done for the patients with various pathological conditions.

\begin{tabular}{|lll|}
\hline Surgical procedures & $\begin{array}{l}\text { No. of } \\
\text { patients }\end{array}$ & Percentage \\
\hline Cystectomy & 127 & 40.06 \\
\hline $\begin{array}{l}\text { Chrompertubatio and } \\
\text { drilling of the ovary }\end{array}$ & 58 & 18.29 \\
\hline Adnexectomia & 34 & 10.72 \\
\hline $\begin{array}{l}\text { Salpingectomy due to } \\
\text { ectopic pregnancy }\end{array}$ & 23 & 7,25 \\
\hline Diagnostic laparoscopy & 19 & 5.99 \\
\hline $\begin{array}{l}\text { Conversion to } \\
\text { laparotomy }\end{array}$ & 13 & 4.10 \\
\hline Salpingectomy & 11 & 3.47 \\
\hline $\begin{array}{l}\text { Occlusion of the } \\
\text { fallopian tubes } \\
\text { (sterilization) }\end{array}$ & 6 & 1.89 \\
\hline Oophorectomy & 11 & 3.47 \\
\hline $\begin{array}{l}\text { Incision of the } \\
\text { fallopian tube and } \\
\text { evacuation of ectopic } \\
\text { pregnancy }\end{array}$ & 6 & 1.89 \\
\hline LAVH & 2 & 0.31 \\
\hline $\begin{array}{l}\text { Incision of the } \\
\text { fallopian tube }\end{array}$ & 1 & 100.0 \\
\hline Resection of fibroids & 4 & 0.31 \\
\hline $\begin{array}{l}\text { Raising and fixing the } \\
\text { uterus }\end{array}$ & 1 & 1.26 \\
\hline Appendectomy & 317 & 0.31 \\
\hline Total & 1 & \\
\hline
\end{tabular}


Table 2 shows the incidence of gynaecological diseases treated laparoscopic surgical technique, Ovarian cyst are most common pathological condition in $43.60 \%$, Infertility in $16.39 \%$ and Ectopic pregnancy in $12.13 \%$. The difference in number of laparoscopic surgical interventions and the number of pathological conditions (295-305) is because some patients had two or more pathological conditions.

Table 3 shows the method of laparoscopic surgical procedures done in patients with various pathological conditions. The most commonly treatment was cystectomy $40.06 \%$, then chromopertubation with ovarian drilling 18:29\% in infertility, and adnexectomy $10.72 \%$.

\section{DISCUSSION}

Laparoscopy is a minimally invasive surgical procedure. Operative laparoscopy offers several advantages to laparotomy, primarily because of better visualization, less tissue trauma, and much shorter recovery time. Laparoscopies were performed under General anesthesia. The whole abdominal cavity was inspected including under surface of diaphragm and liver. Further inspection was done for - Uterus, Fallopian tubes, Ovaries, Pouch of Douglas POD, Adhesion- type and site, Broad ligament, varicosity of vessel, Pelvic peritoneum. Abnormality found was recorded and treated accordingly laparoscopic cystectomy is the preferred approach to managing benign ovarian cysts in adolescents and adults. A retrospective study of 133 females aged 55 years or younger who underwent laparoscopic surgery concluded that the procedure is a safe first-line strategy for cysts in this age group. The intraoperative diagnosis of these cases was highly correlated with the final pathology. ${ }^{3}$ In our study we have similar results. In our study we had 58 (18:29\%) chrompertubatios with ovarian drilling with the aim of treating infertility. Fatum et al suggested that diagnostic laparoscopy should be omitted in patients with suspected unexplained infertility. ${ }^{6}$

Ectopic pregnancy is an increasingly common and potentially catastrophic condition. Misdiagnosis of ectopic pregnancy is quite common. Delayed diagnosis may endanger the life of the patient but also decreases later the likelihood of a future successful pregnancy. ${ }^{7}$ In our study we 37 cases of ectopic pregnancy; $12.13 \%$ of all patients and made 23 salpingectomy (7.25\%) and 6 incision of fallopian tube and evacuation of ectopic pregnancy $(1.89 \%)$. In 8 cases we have had to do laparotomy due to hemorrhage shock.

\section{CONCLUSION}

Laparoscopy involves a minimal damage to body tissues. It is safer than open surgery. Although complications are rarer with laparoscopy but it can occur. In present study there was no mortality. Regarding complications of laparoscopy-In present study there was no major complication. Minor complications included wound infection, abdominal discomfort after laparoscopy4,5. The most common pathological condition was ovarian cysts.

With a careful preoperative screening, the laparoscopic surgery of ovarian cyst is an efficient and safe treatment for adolescents and young adults. The second most common procedure was chromopertubation and drilling ovary, which contributed greatly to the minimally invasive treatment of infertility. Other pathological conditions and surgical procedures were in smaller numbers but contribute to faster treatment, faster recovery and reducing the cost of treatment, and thus raise the level of efficiency.

\section{Funding: No funding sources \\ Conflict of interest: None declared \\ Ethical approval: Not required}

\section{REFERENCES}

1. Spaner SJ, Warnock GL. A brief history of endoscopy, laparoscopy and laparoscopic surgery. J Laparoendosc Adv Surg Tech A. 1997;7(6):369-73.

2. Bosteels J, Van Herendael B, Weyers S, D'Hooghe T. The position of diagnostic laparoscopy in current fertility practice. Human reproduction update. 2007;13(5):477-85.

3. Seckin B, Ozdener T, Tapisiz OL, Batioglu S. Laparoscopic treatment of ovarian cysts in adolescents and young adults. J Pediatr Adolesc Gynecol. 2011;24(5):300-3.

4. Kang SB, Chung HH, Lee HP, Lee JY, Chang YS. Impact of diagnostic laparoscopy on the management of chronic pelvic pain. Surg Endosc. 2007;21(6):916-9.

5. Fuller J, Ashar BS, Carey-Corrado J. Trocar associated injuries and fatalities: an analysis of 1399 reports to the FDA. J Minim Invasive Gynecol. 2005;12(4):302-7.

6. Fatum M, Laufer N, Simon A. Investigation of the infertile couple should diagnostic laparoscopy be performed after normal hysterosalpingography in treating infertility suspected to be of unknown origin? Human Reproduction. 2002;17(1):1-3.

7. Jones EE. Ectopic pregnancy: Common and some uncommon misdiagnosis. Obstet Gynecol Clin North Am. 1991;18:55-72.

Cite this article as: Šuškić A, Šuškić SH, Oprić D, Maksimović S. Role of laparoscopic techniques in the treatment of female genital pathology. Int J Reprod Contracept Obstet Gynecol 2016;5:3693-5. 